\title{
PENGEMBANGAN MODEL PENDIDIKAN NILAI HUMANIS-RELIGIUS BERBASIS KULTUR MADRASAH
}

\author{
Subiyantoro \\ Fakultas Ilmu Tarbiyah dan Keguruan UIN Sunan Kalijaga \\ email: sbytoro@ymail.com
}

\begin{abstract}
Abstrak: Penelitian ini bertujuan menemukan model pendidikan nilai humanis-religius berbasis kultur madrasah. Metode yang digunakan adalah penelitian dan pengembangan dengan pendekatan kualitatif. Proses analisis data dengan menerapkan metode Miles and Huberman, sedangkan tahapan analisisnya dengan model Spradley, dan dalam analisis data ini, juga dilengkapi dengan analisis statistik deskriptif. Hasil penelitian ini dapat dikemukakan sebagai berikut. Pengembangan model pendidikan nilai humanis-religius dapat ditemukan dengan mengikuti langkah-langkah antara lain: (1) memotret kultur madrasah, yang meliputi aspek artifak dan aktivitas kultur; (2) penentuan visi, misi madrasah, dan standar, serta program dalam bidang artifak; dan (3) implementasi pendidikan nilai humanisreligius ini dirancang dan dilaksanakan melalui saluran kultur madrasah.
\end{abstract}

Kata Kunci: model pendidikan nilai humanis-religius, kultur madrasah

\section{DEVELOPING A MODEL OF HUMANISTIC RELIGIOUS VALUE EDUCATION BASED ON ISLAMIC SCHOOL CULTURE}

\begin{abstract}
This study aims to find a model of humanistic-religious value education based on the Islamic school culture. The method employed was the research and development using the qualitative approach. The process of the data analysis applied the method by Miles and Huberman, while the analysis steps employed the model by Spradley; the data analysis was also supplemented by the descriptive statistical analysis. The findings of the study are as follows. The development of a model of humanistic-religious value education was made through the steps of: (1) describing the Islamic school culture, including the material culture and behavioral culture; (2) setting the Islamic school's vision, mission; and (3) designing and implementing the humanistic-religious value education through the Islamic school culture channel.
\end{abstract}

Keyword: humanistic-religious value education model, on the islamic school culture

\section{PENDAHULUAN}

Sebagaimana diketahui pendidikan nasional berfungsi mengembangkan kemampuan dan membentuk watak serta peradaban bangsa yang bermartabat dalam rangka mencerdaskan kehidupan bangsa, bertujuan untuk mengembangkan potensi peserta didik, agar menjadi manusia yang beriman dan bertaqwa kepada Tuhan Yang Maha Esa, berakhlak mulia, sehat, berilmu, cakap, kreatif, mandiri dan menjadi warga negara yang demokratis serta bertanggung jawab (Depdiknas, 2002:1). Namun, kenyataan di lapangan, dengan mengamati realitas out put pendidikan, dapat disaksikan anak-anak muda, pelajar bahkan mahasiswa terlibat berperilaku menyimpang dan melanggar nilai-nilai dasar kemanusiaan. Ketergantungan pada obat terlarang, putus sekolah, perilaku merusak, tawuran, terjadi di berbagai daerah.

Irsyad Sudira penggagas Gerakan Masyarakat Peduli Akhlak Mulia (GMP-AM) tingkat nasional mengungkapkan, telah terjadi penyimpangan perilaku di masyarakat kita. Perilaku yang mengesampingkan rasa malu untuk melakukan hal-hal yang tidak pantas, dekadensi moral dan akhlak, sehingga memicu keterpurukan kondisi bangsa di semua sektor. Dalam kaitan itu, seorang bijak mengatakan: "When wealth is lost, nothing is lost. When health is lost something is lost. When character is lost, everything is lost". Bila harta kekayan yang hilang, belum berarti kehilangan sesuatu. Bila kesehatan yang 
hilang, barulah ada sesuatu yang hilang. Bila karakter yang hilang, berarti hilanglah segalanya (Prasetyo, 2007:108).

Penelitian ini dilakukan bagi terbentuknya peserta didik yang memiliki nilai-nilai kemanusiaan (humanistik) dan nilai-nilai keberagamaan (religiusitas). Penanaman nilai tersebut dibangun dengan menerapkan pendidikan yang humanis-religius melalui saluran kultur madrasah. Hal ini dilakukan karena program aksi untuk peningkatan mutu sekolah secara konvensional selalu menekankan pada aspek peningkatan mutu proses belajar mengajar, sedikit menyentuh manajemen sekolah, dan sama sekali tidak menyentuh aspek kultur sekolah (Depdiknas, 2002:4).

Prinsip humanistik dalam pendidikan adalah menciptakan lingkungan pembelajaran yang membuat anak-anak terbebas dari persaingan intens, disiplin kaku, dan rasa takut akan kegagalan. Hubungan antara peserta didik dan pendidik dapat menciptakan hubungan yang merembes pada kepercayaan dan rasa keamanan, sehingga muncul kreativitas positif siswa (Knight, 1982:88). Untuk mengungkap fenomena religiusitas secara teoretis, dikemukakan konsep yang populer yakni rumusan Glock \& Stark bahwa religiusitas terdiri dari lima dimensi (1) religious belief; (2) religious practice; (3) religious feeling; (4) religious knowledge; (5) religious effects (Stark dan Glock, 1965:18-38). Rumusan tersebut diadaptasi oleh Nashori dan Mucharam (2002:7) bahwa religiusitas islami terdiri dari lima aspek yakni (1) ideological (aspek akidah); (2) ritualistic (aspek ibadah); (3) experiential (aspek ihsan); (4) intellectual (aspek ilmu); dan (5) consequential (aspek dampak keagamaan). Lima aspek tersebut semestinya menyatu dalam diri seorang muslim, sebagaimana dikuatkan oleh Al-Attas (1982:56), bahwa makna keberislaman menunjuk kepada iman (akidah) dan praktik-praktik ajaran yang dianut oleh seorang muslim dalam kehidupan sehari-hari (kepribadian muslim).

Melalui saluran kultur sekolah dan pola pendidikan humanis-religius diharapkan dapat terwujud aktualisasi nilai-nilai religius. Nilainilai religius itu meliputi nilai iman, ilmu, ritual,eksperiensial dan dampak keagamaan yang akan mewarnai serta melahirkan aktualisasi nilai-nilai humanis. Adapun nilai humanis diantaranya meliputi nilai kebebasan, rasa aman, kreativitas, aktualisasi diri, kerjasama, percaya diri, etis dan moral, kebenaran, pengawasan diri, dan pertanggungjawaban di dunia dan akhirat.

Hasil penelitian Usman dan Raharjo (2013:5-9) menunjukkan bahwa strategi pembelajaran meliputi empat kategori (1) keteladanan; (2) pembelajaran di kelas; (3) kultur (budaya) sekolah; dan (4) penguatan. Kultur sekolah merupakan keyakinan-keyakinan, nilai-nilai, norma-norma, tradisi bersama yang mengikat kebersamaan seluruh warga sekolah. Dari hasil penelitiannya disebutkan bahwa, penciptaan kultur sekolah dilakukan melalui penugasan, pembiasaan, pelatihan, pengajaran, pengarahan dan keteladanan. Kultur sekolah merupakan salah satu kategori dari strategi pembelajaran. Di dalam penelitian ini, kultur madrasah dijadikan saluran dalam pendidikan nilai, serta kultur madrasah diciptakan melalui kegiatankegiatan.

Penelitian Manshur (2012:512-523) mengungkap bahwa penerapan sistem nilai sosial terwujud apabila (1) terlaksana sistem kebebasan yang bertanggung jawab; (2) sistem nilai kesederhanaan kesahajaan; (3) sistem nilai kebersamaan. Penerapan sistem nilai agama terwujud apabila (1) terlaksana sistem nilai ibadah; dan (2) sistem nilai kerendahan hati. Sejalan dengan penelitin tersebut, maka penelitian ini mengembangkan sistem nilai kemanusiaan dan sistem nilai keberagamaan.

Penelitian ini berupaya menemukan pola pendidikan nilai humanis-religius siswa berbasis kultur madrasah, untuk membangun karakter anak yang berkepribadian humanisreligius. Artinya, bagaimana pola penanaman dan penghayatan nilai humanis-religius siswa dibangun melalui kultur madrasah, "atmosfer" madrasah, dikemas melalui berbagai kegiatan dan aktivitas yang sengaja diciptakan, untuk membentuk siswa yang memiliki kepribadian spiritual keberagamaan, dan memiliki penghayatan humanistis yang peka terhadap lingkung- 
an sosial.Tujuan penelitian ini adalah untuk menemukan pengembangan model dalam upaya pendidikan nilai humanis-religius siswa berbasis kultur madrasah. Secara rinci tujuan penelitian umum tersebut, diturunkan ke dalam empat tujuan yang lebih khusus. Salah satu tujuan paling pokok adalah menemukan model pendidikan nilai humanis-religius berbasis kultur madrasah, dan mengetahui perubahan yang terjadi pada diri siswa.

\section{METODE}

\section{Prosedur Pengembangan}

Penelitian ini merupakan penelitian pengembangan (Research and Development) dengan pendekatan kualitatif. Penelitian diawali dengan "memotret" kultur Madrasah Aliyah Negeri (MAN) se-Kabupaten Kulon Progo, dan setelah ditemukan model hipotetik pengembangan melalui FGD, hasil validasi, penentuan standar dan konsep pengembangan, kemudian diujicobakan di MAN Wates 1 selama enam bulan, dengan ditangani oleh tim pengembang. Proses analisis dengan model Miles and Huberman dan tahapan analisis dengan model Spradley, dilengkapi dengan analisis statistik deskriptif. Borg \& Gall (1983: 772) menguraikan tahap-tahap dalam siklus penelitian pengembangan, terdiri atas (1) mempelajari penemuan-penemuan penelitian yang sesuai dengan produk yang akan dikembangkan; (2) melakukan uji lapangan di tempat dimana akan dipakai secepatnya; dan (3) melakukan revisi terhadap kekurangan yang dijumpai pada tahap uji lapangan.

Penelitian pengembangan ini menempuh prosedur meliputi tahap studi pendahuluan dengan "memotret" kultur madrasah dalam pola pendidikan nilai di MAN se-Kabupaten Kulon Progo, yang terdiri dari tiga MAN. Setelah dilakukan pemaknaan terhadap "potret" kultur tersebut, maka ditemukan model hipotetik pendidikan nilai humanis-religius. Berdasarkan temuan model tersebut, dilakukan studi pengembangan dengan diuji coba awal dan divalidasi.Validasi didasarkan atas masukan dari Focus Group Discussion (FGD). Peserta FGD adalah para pakar pendidikan yang dipandang memiliki keahlian dalam bidang yang relevan dengan penelitian ini, sehingga dapat memberikan sumbangan pemikiran yang memadahi.

Setelah tahapan tersebut, kemudian dilakukan uji coba penerapan, evaluasi, penyempurnaan dan ditemukan model final. Untuk mengetahui keefektifan model, dilakukan pengukuran secara kualitatif dan secara kuantitatif tentang aktualisasi nilai humanis-religius siswa dan persepsi siswa mengenai keefektifan pendidikan nilai melalui kultur madrasah. Pengukuran dilakukan sebelum tindakan uji coba dan sesudah uji coba. Uji coba produk mengikuti langkah, menampilkan desain uji coba (gambar 15), subyek coba (terhadap 44 siswa bermasalah di madrasah). Tahap-tahap pengembangan tersebut, tertuang dalam Skema 1.

Instrumen pengumpulan data dalam penelitian kualitatif ini, peneliti sebagai instrumen kunci (key instruments). Pengukuran kualitatif berupa observasi perilaku, penanyaan langsung, pengungkapan langsung, dan pengukuran terselubung. Uji keabsahan data kualitatif meliputi (1) uji credibility (validitas internal); (2) transferability (validitas eksternal); (3) dependability (reliabilitas); dan (4) confirmability (objektivitas). Uji credibility data meliputi perpanjangan pengamatan, peningkatan ketekunan, trianggulasi, analisis kasus negatif dan member check. Trianggulasi dalam pengujian kredibilitas dilakukan untuk pengecekan data dari berbagai sumber dengan berbagai cara dan berbagai waktu. Trianggulasi berdasar sumber data seperti satu sumber dari siswa, dilakukan trianggulasi data kepada guru, teman, dan orang tua. Trianggulasi tehnik dilakukan dengan wawancara, observasi, kuesioner, dan dokumentasi (Sugiyono, 2006:374). Instrumen yang digunakan untuk pengukuran sikap digunakan skala likert, yang meliputi (1) skala pengukuran karakteristik nilai humanis-religiusitas siswa, serta (2) skala persepsi siswa tentang peran dan fungsi kultur sekolah sebagai saluran pendidikan nilai humanis-religius. Penyusunan skala ini didasarkan pada kisi-kisi skala yang meliputi variabel, aspek, indikator dan jumlah serta nomor item. Angket skala sikap digunakan setelah melalui uji validitas dan reliabilitas. 
Analisis data selama di lapangan dilakukan secara interaktif dan berlangsung terus sampai tuntas, meliputi proses data reduction, data display, dan conclution drawing/veryvication (Miles and Huberman 1992:15).

Proses analisis ini terdiri dari tiga alur kegiatan secara bersamaan, berlanjut, berulang terus menerus, sebagai rangkaian kegiatan analisis yang saling susul-menyusul. Tahapan analisis menggunakan analisis model Spradley, proses penelitiannya berangkat dari yang luas, kemudian memfokus dan meluas lagi. Tahapan yang dilakukan yakni analisis domain, taksonomi, komponensial dan analisis tema kultural. Pengukuran dalam penelitian ini juga menerapkan analisis statistik deskriptif. Statistik deskriptif digunakan untuk menganalisis hasil instrumen pengukuran sikap dan nilai humanisreligius serta persepsi siswa terhadap efektifitas saluran kultur sekolah. Hasil penelitian yang ditampilkan dalam statistik deskriptif ini berupa tabel, grafik dan persentase hasil pengukuran.
HASIL DAN PEMBAHASAN

\section{Kandungan Makna Hasil Potret Kultur Madrasah}

Hasil penelitian ini meliputi aspek artifak (material culture) dan aktivitas kultur (behavioral culture). Kedua aspek tersebut meliputi fenomena kedisiplinan secara kultural, kebersihan secara kultural, hubungan antarwarga sekolah, baik dalam kegiatan intrakurikuler maupun ekstrakurikuler, kegiatankegiatan yang diadakan di sekolah dengan pola tertentu, seperti shalat malam dan lain-lain, sehingga bisa membangun tanggung jawab berdasar norma-norma, kejujuran, dan keberagamaan siswa secara utuh. Aspek keberagamaan lebih difokuskan pada shalat wajib siswa, mengingat aspek ritual shalat wajib lima waktu mengandung lima dimensi keberagamaan (iman, ilmu, ritual, penghayatan, dampak keagamaan). Pada dimensi dampak keagamaan, terkandung aspek kehidupan yang lain, yang dalam hal ini dibatasi pada nilai humanitas. Pengukuran aktualisasi nilai humanis-religius siswa dilakukan untuk mengetahui kefektifan model pendidikan nilai yang diuji cobakan.

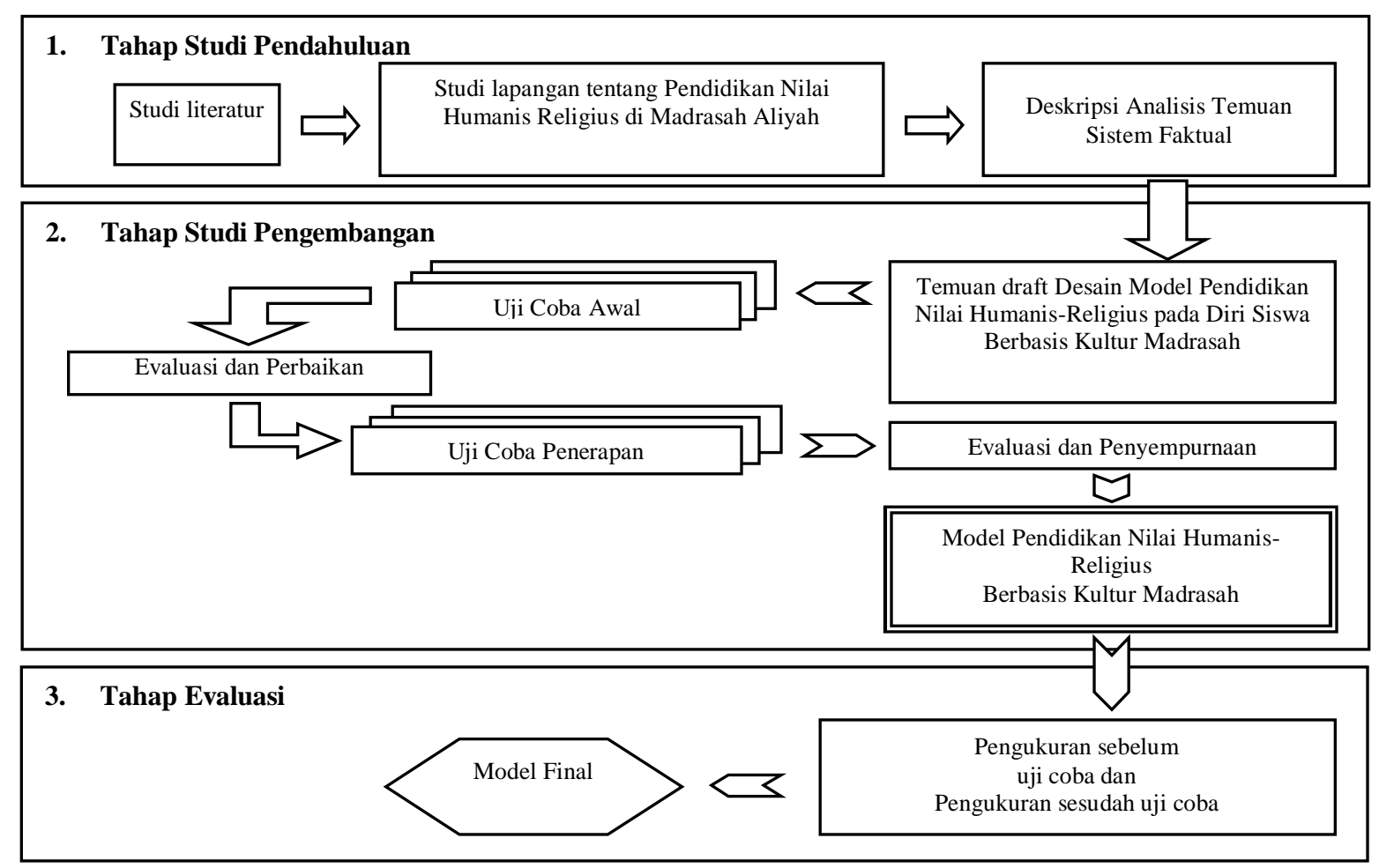

Gambar 1. Skema Langkah-langkah Pengembangan 
Instrumen skala likert, setelah melalui uji reliabilitas dan validitasnya, angket yang valid dan reliabel untuk skala sikap karakteristik nilai religiusitas siswa 88 item. Skala sikap karakteristik nilai humanis 58 item dan skala persepsi siswa tentang pendidikan nilai melalui saluran kultur 38 item. Skala sikap tersebut terdiri dari lima pilihan bertingkat, masing-masing diberi skor satu sampai dengan lima, diberikan kepada 46 siswa bermasalah, dan yang memenuhi syarat analisis ada 39 siswa. Perhitungan skala sikap religiusitas skor minimal 88, skor maksimal 440. Skala sikap humanis skor minimal 58, skor maksimal 290. Skala persepsi siswa skor minimal 38, skor maksimal 190. Perolehan skor masing-masing dimensi tersebut dibagi ke dalam tiga tingkatan, dengan jumlah interval sama pada tiap tingkat. Selanjutnya diperoleh gambaran siswa dengan kategori sikap religius kurang, sedang dan tinggi, kategori sikap humanis kurang, sedang dan tinggi, serta kategori persepsi siswa terhadap keefektifannya kurang, sedang, efektif dan sangat efektif. Hasil penelitian mengenai aktualisasi nilai humanisreligius siswa sebelum tindakan dan setelah tindakan uji coba, dapat ditampilkan pada Grafik $1-9$.

Grafik Aktualisasi Nilai Humanis-Religius Siswa sebelum Tindakan

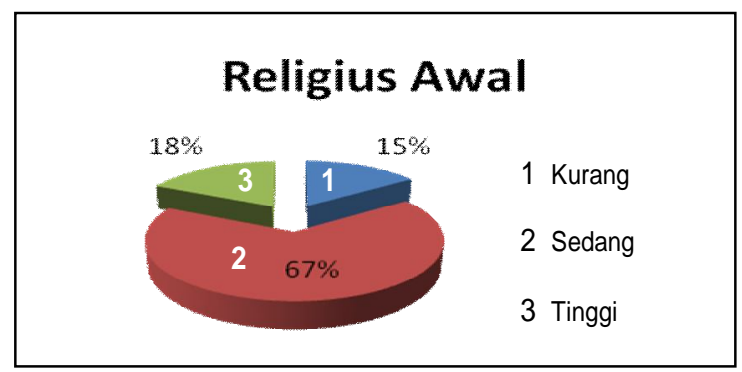

Grafik 1. Hasil Pengukuran Religiusitas Awal

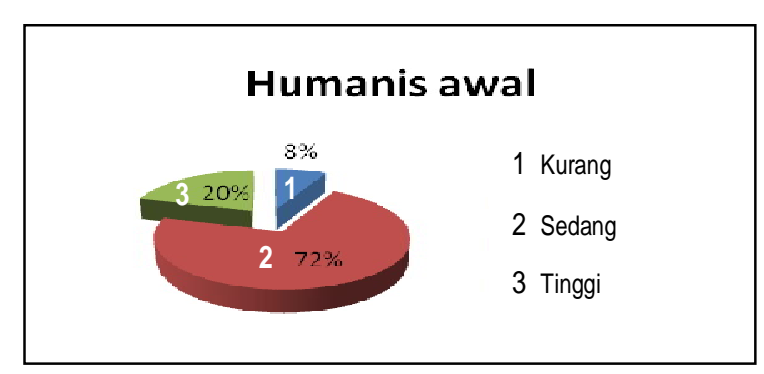

Grafik 2. Humanis Awal

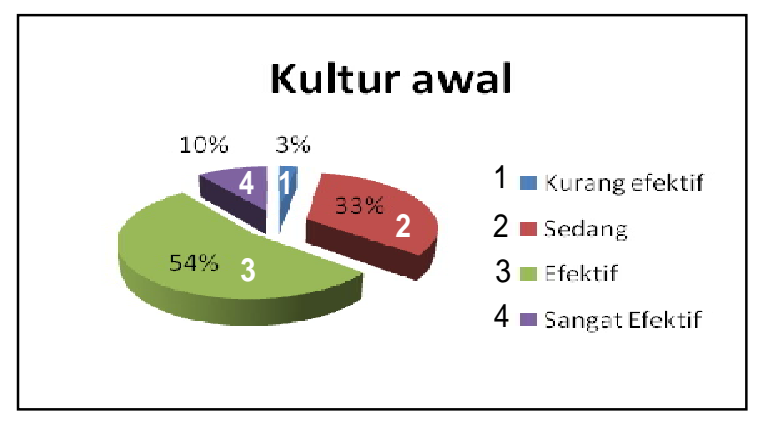

Grafik 3. Kultur Awal

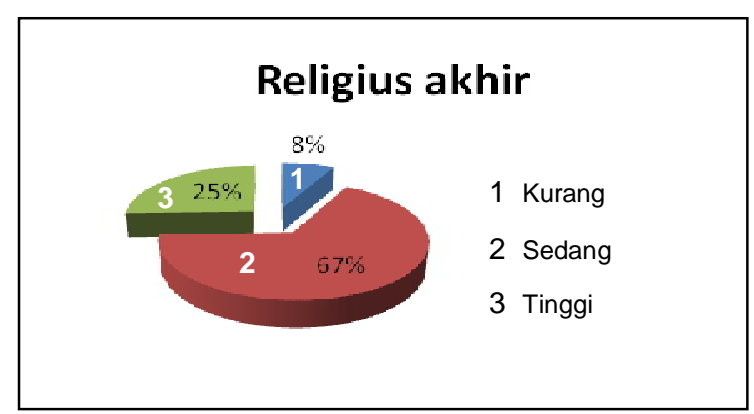

Grafik 4. Religiusitas Akhir

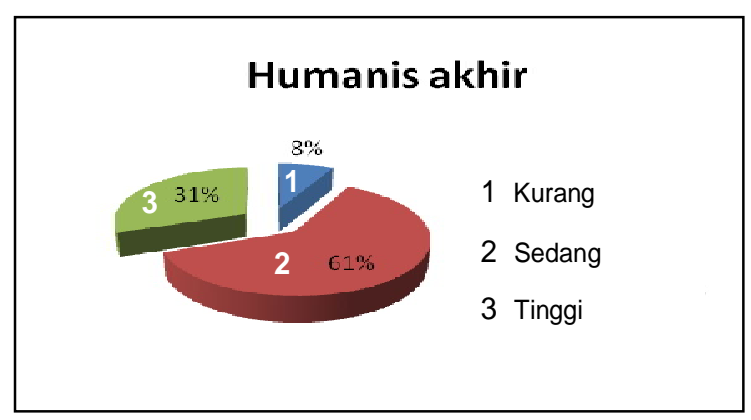

Grafik 5. Humanis Akhir



Grafik 6. Kultur Akhir 


\section{Grafik Hasil Angket sebelum Tindakan dan sesudah Tindakan}

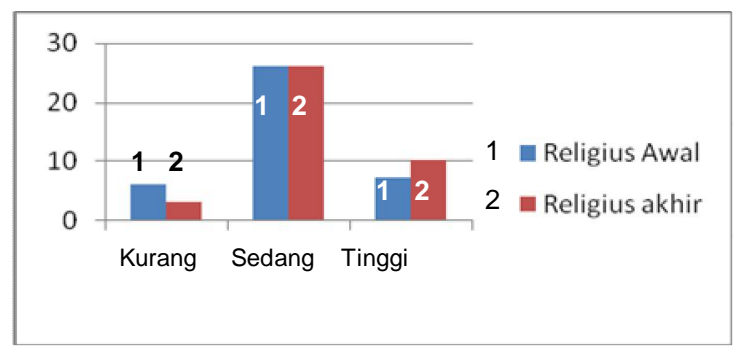

Grafik 7. Religiusitas Awal dan Akhir

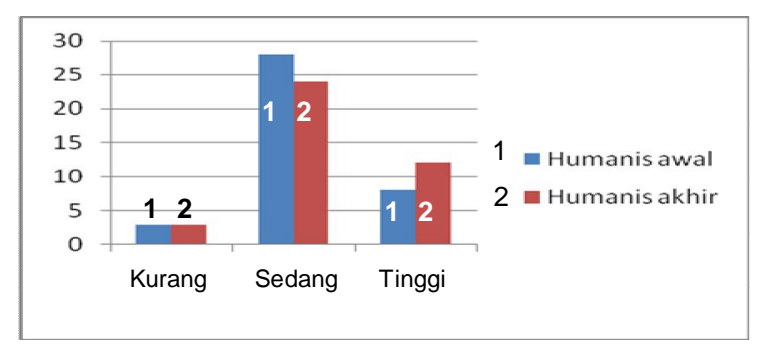

Grafik 8. Humanis Awal dan Akhir

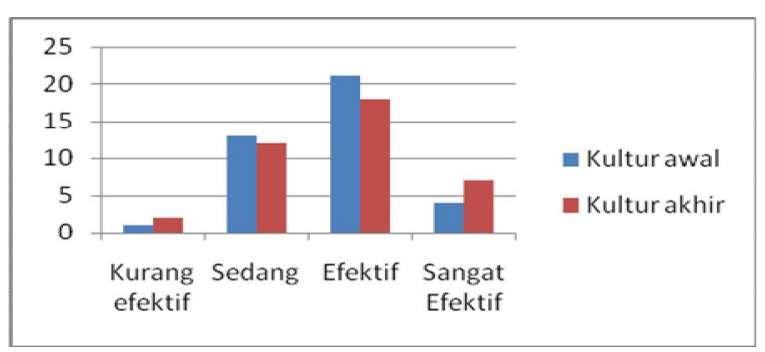

\section{Grafik 9. Hasil Pengukuran Kultur Awal dan Akhir}

Sebagaimana telah dijelaskan di atas, bahwa hasil pengukuran masing-masing dimensi dikategorikan menjadi kurang, sedang, dan tinggi. Oleh karena itu, aktualisasi religiusitas awal, diperoleh kategori sedang (15\%), kategori religius (67\%), dan sangat religius (18\%). Pada aktualisasi nilai humanis awal kategori sedang (8\%), humanis $(72 \%)$ dan sangat humanis (20\%). Pada efektivitas saluran kultur awal, kategori kurang efektif (3\%), kategori sedang (33\%), kategori efektif (54\%), dan kategori sangat efektif (10\%). Pada aktualisasi nilai religius akhir, diperoleh kategori sedang $(8 \%)$, religius $(67 \%)$, dan sangat religius $(25 \%)$. Aktualisasi nilai humanis akhir, kategori sedang (8\%), humanis $(61 \%)$, dan sangat humanis (31\%).
Pada keefektifan saluran kultur akhir, kategori kurang efektif (5\%), sedang (31\%), efektif (46\%), dan sangat efektif (18\%).

Berdasarkan grafik sebelum dan setelah tindakan, peningkatan aktualisasi nilai religiousitas, ada pada kategori sangat religius, dan terjadi penurunan pada kategori sedang. Maknanya bahwa, setelah dilakukan tindakan, aktualisasi nilai religiusitas siswa meningkat pada siswa-siswa yang bersungguh-sungguh mengikuti kegiatan. Demikian juga pada aktualisasi nilai humanis, peningkatan terjadi juga pada kategori sangat humanis, dan penurunan terjadi pada kategori humanis. Pada efektivitas kultur, peningkatan terjadi pada kategori sangat efektif dan penurunan pada kategori sedang. Hal ini mengandung makna bahwa, tindakan yang dilakukan melalui saluran kurtur sangat efektif. Dengan terjadinya peningkatan aktualisasi nilai tersebut, baik berdasar pengamatan, observasi partisipan, depth interview (paradigma kualitatif), maupun hasil pengukuran angket (paradigma kuantitatif), yang berarti bahwa pola pengembangan yang dilakukan dapat dikategorikan efektif.

\section{Kultur Sekolah sebagai Basis Pendidikan Nilai}

Sekolah sebagai suatu sistem memiliki tiga aspek pokok yang sangat berkaitan erat dengan mutu sekolah, yakni proses belajar mengajar, kepemimpinan dan manajemen sekolah, serta kultur sekolah. Program aksi untuk peningkatan mutu sekolah secara konvensional senantiasa menekankan pada aspek pertama, yakni meningkatkan mutu proses belajar mengajar, sedikit menyentuh aspek kepemimpinan dan manajemen sekolah, dan sama sekali tidak pernah menyentuh aspek kultur sekolah. Untuk itu perlu dikaji untuk melakukan pendekatan inkonvensional, yakni meningkatkan mutu dengan mengembangkan kultur sekolah (Depdiknas, 2002:4).

Adapun komponen yang diperlukan dalam pengembangan budaya sekolah adalah (1) menerapkan dan mengembangkan nilai-nilai kehidupan sekolah secara demokratis; (2) membentuk budaya kerja sama (school corporate cul- 
ture); (3) menumbuhkan budaya profesionalisme warga sekolah; (4) menciptakan iklim sekolah yang kondusif-akademis; (5) menumbuhkembangkan keragaman budaya dalam kehidupan sekolah (Ditjen Dikdasmen, Depdiknas, 2002: 21).

Stop dan Smith sebagaimana dikutip tim peneliti PPs-UNY (2003:8) membagi tiga lapisan kultur yakni dapat divisualisasikan dalam Gambar 2.

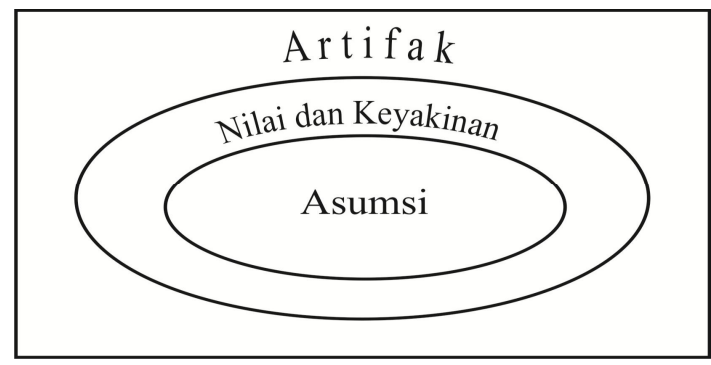

Gambar 3. Lapisan-lapisan Kultur

Artifak merupakan lapisan kultur sekolah yang mudah diamati seperti ritual sehari-hari di sekolah, berbagai upacara, benda-benda serta aneka ragam kebiasaan di sekolah, lapisan yang lebih dalam berupa nilai-nilai dan keyakinankeyakinan yang ada di sekolah dan ini menjadi ciri utama suatu sekolah. Lapisan paling dalam adalah asumsi-asumsi, nilai-nilai, simbol-simbol yang tidak dapat dikenali tetapi terus berdampak terhadap perilaku sekolah. Lapisan kultur tersebut dapat diilustrasikan seperti pada Gambar 4.

Dalam memerankan kultur organisasi, maka fungsi kepemimpinan sangat dominan karena kepemimpinan di sekolah mempunyai tugas (1) perencana, (2) alokator sumber daya, (3) koordinator, (4) supervisor, (5) penyebar informasi, (6) ahli hukum, (7) penjaga pintu, dan (8) analis (Deal dan Peterson, 1994: 19). Selain itu Kepala Sekolah secara simbolik mempunyai delapan peran aspek kunci: (1) sejarawan, (2) detektif antropologis, (3) penghayal, (4) simbol, (5) pembuat tembikar (6) penyair, (7) aktor, dan (8) penyembuh (Deal \& Peterson, 1994:28). Mencermati peran dan fungsi tersebut, maka kepala sekolah memegang peran dominan dalam membingkai dan mengembangkan kultur sekolah atau madrasah. Pimpinan sebagai de- tektif antropologi, dia harus mendengarkan dan memberikan petunjuk untuk rutinitas dan ritual sekolah atau madrasah, mengukur norma-norma, nilai dan keyakinan yang ada serta menggali jaringan informal.

\section{Nilai-nilai Humanis-Religius yang Ditanam- kan kepada Siswa}

Nilai merupakan persoalan umat manusia; sebagai makhluk sosial dalam kehidupannya, manusia tidak bisa lepas dari nilai-nilai yang melingkupinya. Setiap masyarakat memiliki sesuatu yang dihargai, dan sesuatu yang dihargai itu memiliki nilai tinggi. Pendapat Newcomb, nilai merupakan tujuan terpisah yang terjadi secara luar biasa dan di sekelilingnya terdapat pola-pola tingkah laku yang diorganisasi. Dia menggambarkan hubungan antara nilai, sikap, dan motif seperti terlihat pada Gambar 5.

Berdasar Gambar tersebut dapat dijelaskan bahwa sikap, lahir dari nilai, sebagai tujuan-tujuan umum yang hanya mencakup polapola perilaku. ditegaskan Newcomb bahwa salah satu fungsi sikap adalah memberi ungkapan yang positif terhadap nilai-nilai sentral yang dikehendaki seseorang (Mulyana, 2004:43).

Prinsip pendidikan humanistik (Knight, 1982:88) serta kemungkinan nilai yang timbul antara lain: Penciptaan lingkungan belajar bebas dari persaingan intens, disiplin kaku, dan takut gagal, memungkinkan tumbuhnya nilai kebebasan untuk berkembang. Penciptaan lingkungan pembelajaran yang "akrab" antar pendidik dengan subjek didik memungkinkan tumbuhnya rasa aman, rasa kepercayaan, sehingga dengan terbebasnya dari rasa takut untuk tumbuhnya kreativitas. Penciptaan lingkungan pembelajaran yang tidak mengekang mengarah kepada tumbuhnya 'aktualisasi diri' bukan penumpukan pengetahuan.

Untuk mengungkap nilai religiusitas, dikemukakan fenomena keberagamaan, yakni salah satu konsep yang banyak dianut para ahli psikologi dan sosiologi yaitu konsep religiusitas rumusan Glock \& Stark sebagaimana disebutkan di atas. Selanjutnya teori ini digunakan untuk mengupas nilai humanis-religius. Bahwa 
unsur-unsur keberagamaan meliputi (1) kepercayaan keagamaan (religious belief) atau aqidah sebagai dimensi ideologi dan konseptual, (2) praktik keagamaan (religious practice) sebagai dimensi ritual. (3) Perasaan atau penghayatan keberagamaan (religious feeling) sebagai dimensi pengalaman, (4) pengetahuan keagamaan (religious knowledge) sebagai dimensi intelektual, dan (5) dampak keagamaan (religious effects) sebagai dimensi konsekwen (akibat) yang ditampilkan dalam perbuatan yang mencerminkan citra diri seseorang.

Nilai iman atau lengkapnya religiusitas itu menjadi penentu apakah suatu aktivitas itu bernilai amal shaleh (nilai ibadah) ataukah sekedar nilai duniawi saja yang kurang bermakna dalam kehidupan duniawi dan ukhrowi. Nilai-nilai humanis-religius yang menjadi target tujuan pendidikan nilai ini, dapat digambarkan dalam skema Gambar 14.

Skema tersebut menunjukkan bahwa nilai iman itu menjadi penentu nilai suatu aktivitas lain, yang dibingkai dengan nilai-nilai religiusitas yang lain. Nilai iman dan nilai religiu- sitas ini akan mejadi penentu, pendorong gerak, dan kontrol terhadap nilai-nilai kemanusiaan yang lain. Dalam pandangan agama Islam, nilai Iman menduduki tempat yang lebih tinggi daripada Islam itu sendiri. Firman Allah: "Orangorang Arab Badui itu berkata: 'Kami telah beriman'. Katakanlah (kepada mereka): 'Kamu belum beriman', tetapi katakanlah 'kami telah Islam', karena iman itu belum masuk ke dalam hatimu..." (QS. al- Hujurat [44]:14)

Berdasar ayat itu, maka kedudukan iman itu sangat penting dan merupakan ruh penggerak dari dalam lubuk hati ke otak atau pikiran manusia, dan otak yang menyuruh anggota badan untuk beraktivitas. Oleh karena itu, wajar kalau masih banyak orang Islam melakukan kemaksiatan, barangkali mereka baru 'Islam' tetapi belum beriman dalam hatinya. Berdasar firman Allah SWT, orang yang tidak beriman kepada hari akhirat, sungguh menyimpang dari jalan lurus. "Dan sesungguhnya orang-orang yang tidak beriman kepada negeri akhirat benar-benar menyimpang dari jalan yang lurus". (QS. al- Mu'minun [23] :74).

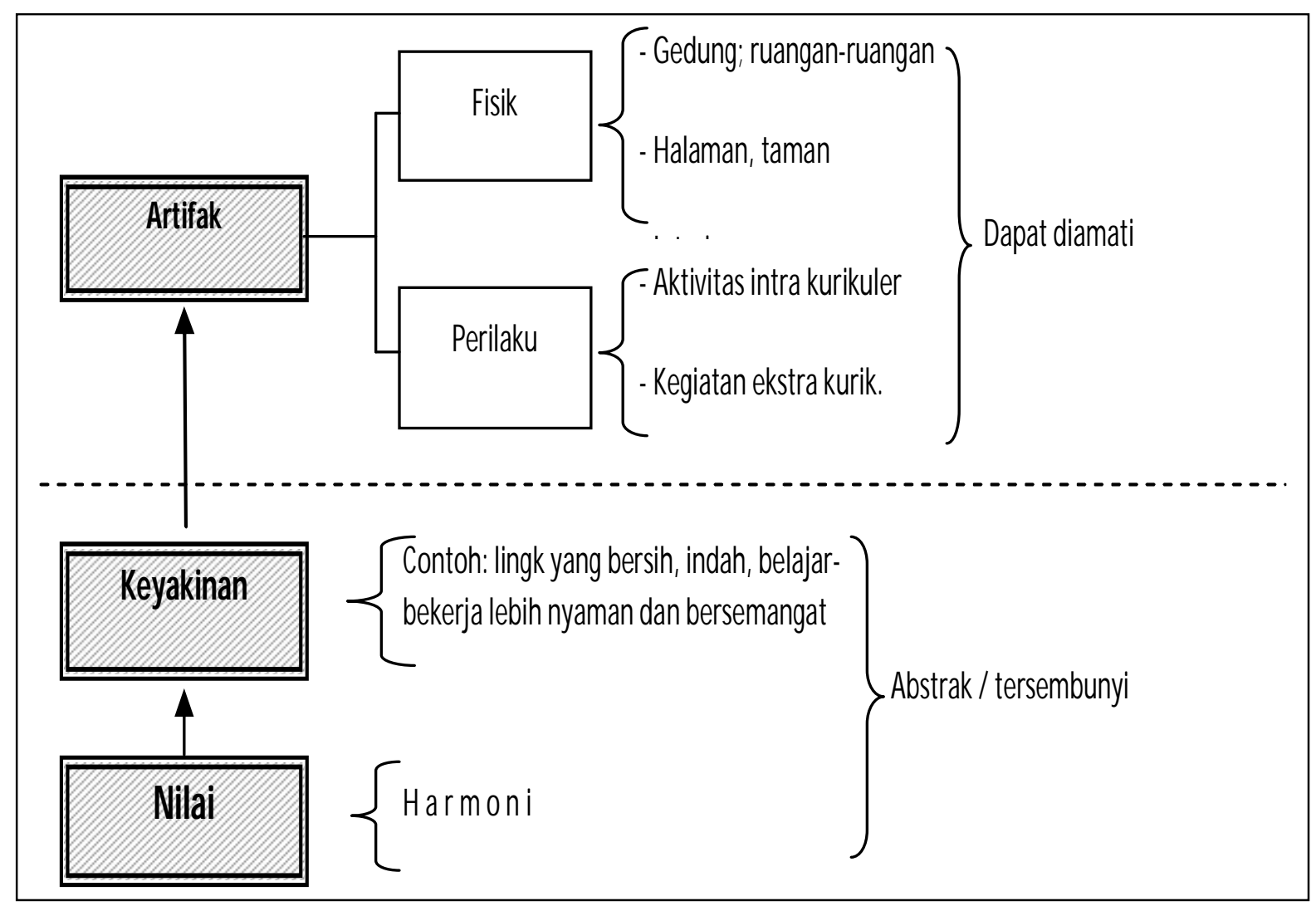

Gambar 4. Contoh Lapisan Kultur Sekolah 


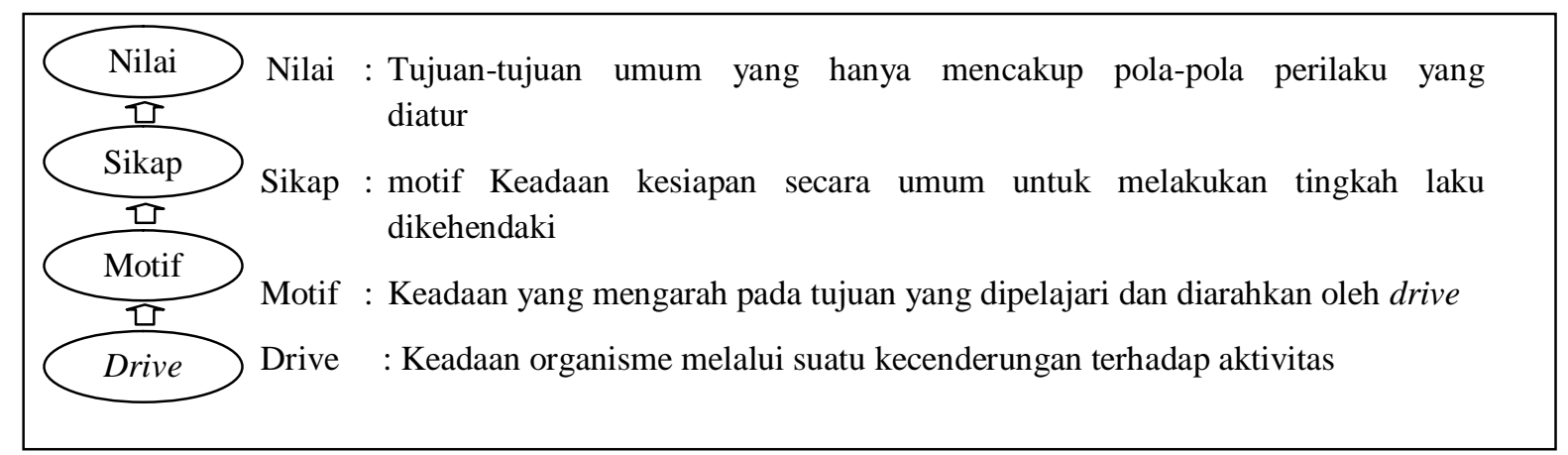

Gambar 5. Hubungan Drive, Motif, Sikap dan Nilai

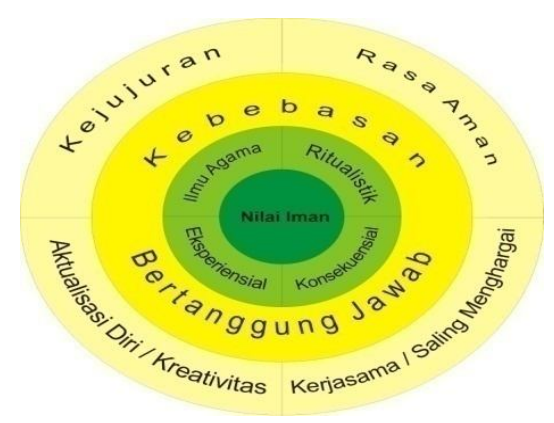

Gambar 6. Skema Nilai Humanis-Religius

Berdasar ayat tersebut, bahwa orang bisa lurus, kalau ada iman kepada hari akhirat. Orang benar-benar akan menyimpang hidupnya ketika tiada iman. Karena dengan iman ini, orang yakin segala sepak terjang hidup di dunia ini (tanpa kecuali) akan dipertanggungjawabkan di akhirat. "Barangsiapa yang mengerjakan kebaikan seberat dzarah pun, niscaya dia akan melihat (balasan)-Nya. Dan barangsiapa yang mengerjakan kejahatan seberat dzarah pun, niscaya dia akan melihat (balasan)-Nya pula”. (QS. AzZalzalah [99] :7-8).

\section{Desain Produk Pendidikan Nilai Humanis- Religius Berbasis Kultur Madrasah}

Pendidikan humanis, sejalan dengan penyokongnya dari teori pendidikan progresivisme, yang memiliki prinsip-prinsip sebagai berikut.

- Tujuan pendidikan dan proses pendidikan berasal dari anak, maka pendidikan menyesuaikan dengan kebutuhan dan minat anak. Jadi subjek didik pada titik sumbu sekolah. Ketertarikan anak adalah titik tolak bagi pengalaman belajar.
- Subjek-subjek didik adalah aktif bukan pasif. Anak bukan makhluk pasif yang mengisi pikirannya banyak informasi dari guru. Mereka makhluk dinamis yang berkeinginan belajar jika tidak dibuat frustasi oleh orang dewasa.

- Peran guru adalah sebagai penasihat, pembimbing dan pemandu, daripada sebagai rujukan otoriter dan pengarah ruang kelas. Peran guru dapat dilihat sebagai peran membantu subjek didik belajar: bagaimana belajar mandiri".

- Sekolah dipandang sebagai sebuah dunia kecil (miniatur) dari masyarakat besar. Pendidikan tidak sekedar dibatasi sebagai kegiatan di dalam kelas dengan dibatasi empat dinding sehingga terpisah dari kehidupan masyarakat luas pendidikan bisa bermakna apabila dapat dimanfaatkan dalam kehidupan masyarakat.

- Aktivitas belajar memfokuskan pada pemecahan masalah daripada metode artifisial untuk pengajaran kajian. Atmosfer sosial sekolah harus kooperatif dan demokratis.

Pendidikan nilai humanis religius ini dikemas melalui saluran-saluran kultur sekolah yang disebut artifak yang meliputi: (1) sistem kepemimpinan; (2) model hubungan antar warga di sekolah (human relation); (3) pembelajaran di kelas; (4) kegiatan-kegiatan ekstrakurikuler; (5) bimbingan ibadah; (6) pelayanan bimbingan konseling; (7) audiensi dengan orang tua peserta didik dan juga sarana fisik ataupun media pendukung lainnya, sebagaimana konseptual modelnya dituangkan seperti Gambar 7. 




Gambar 7. Konseptual Model Desain Produk Pendidikan Nilai Humanis-Religius

\section{Penentuan Standar}

\section{Visi}

Visi dibangun berdasar identifikasi kultur madrasah dan didasarkan pada teori yang ada. Rancangan visinya adalah "Terbentuknya Insan Cendekia yang Handal, Memiliki Sifat dan Sikap Nilai-nilai Humanis-Religius yang Utuh, serta Unggul dalam Keterampilan Hidup".

\section{Misi}

(1) Melaksanakan pembelajaran efektif optimal sesuai prinsip-prinsip pendidikan humanis-religius. (2) Mengoptimalkan pembelajaran pengembangan diri siswa berdasarkan minat, bakat, dan pilihan siswa. (3) Mengembangkan kegiatan-kegiatan yang bersifat ekstra kuri- kuler/organisasi intra sekolah dengan prinsip pendidikan humanis-religius dengan model pelaksanaan "dari", "oleh", dan "untuk" siswa, di bawah fasilitator guru. (4) Mengembangkan "kepemimpinan tim" bagi pemberdayaan sekolah, dengan sistem manajemen partisipatif, akomodatif, demokratis, dan keterbukaan.

\section{Standar}

Dalam hal intelektualitas anak mencapai ketuntasan belajar, berkepribadian muslim utuh. Potensi siswa tergali serta berkembang sesuai minat dan bakat masing-masing. Kreativitas siswa berkembang, bertanggung jawab, siswa merasa aman dalam mengikuti kegiatan di sekolah. Siswa mampu memimpin, jujur, bekerja keras, 
berdisiplin tinggi, ketaatan yang tidak dipaksapaksa, toleransi, dan kerja sama. Aktivitas kehidupan siswa terstandar dalam bingkai norma agama. Pelaksanaan Pendidikan melalui Saluran Kultur dapat dilihat pada Gambar 7.

\section{Sistem Kepemimpinan}

Selain perlu memahami konsep budaya sekolah, kepala sekolah juga perlu melakukan beberapa hal, yaitu: menerapkan serta mengembangkan nilai-nilai kehidupan sekolah yang demokratis; membentuk budaya kerjasama (school corporate culture); menumbuhkan budaya profesionalisme warga sekolah; menciptakan iklim sekolah yang kondusif akademis; dan menumbuhkembangkan keragaman budaya dalam kehidupan sosial.

\section{Desain Pelaksanaan Pendidikan Nilai Humanis-Religius}

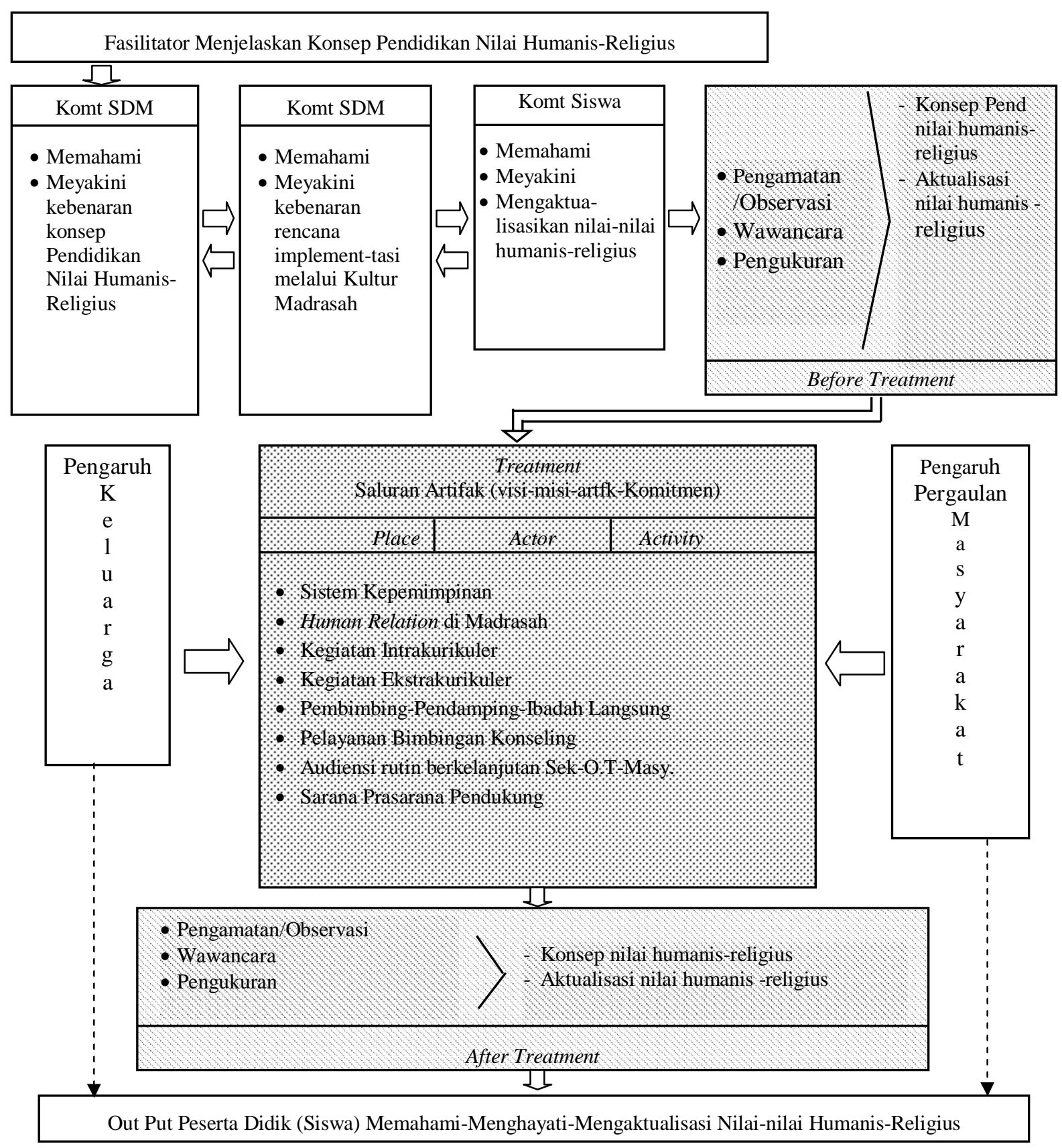

Gambar 8. Konseptual Model Alur Pelaksanaan Pendidikan Nilai Humanis-Religius 
Ciri kepemimpinan kepala sekolah yang berkualitas adalah selalu melaksanakan prinsipprinsip kepemimpinan yang berlaku secara umum, yakni: Konstruktif, artinya kepala sekolah selalu mendorong dan membina staf agar berkembang secara optimal. Kreatif, artinya kepala sekolah selalu mencari gagasan-gagasan baru. Partisipatif, yakni mendorong keterlibatan semua pihak. Kooperatif, yakni mementingkan kerjasama dengan staf dan pihak-pihak terkait. Delegatif, berupaya mendelegasikan tugas kepada staf dengan deskripsi tugas/jabatan yang jelas. Integratif, artinya mengintegrasikan semua kegiatan agar tercipta sinergi untuk mencapai tujuan. Rasional dan objektif dalam melaksanakan tugas. Pragmatis, diartikan dalam menetapkan kebijakan atau target. Keteladanan, adaptabel dan fleksibel, bahwa kepala sekolah harus dapat beradaptasi dan fleksibel dalam menghadapi situasi baru (Depdiknas, 2002:624).

\section{Hubungan antarwarga Sekolah (Human Re- lation)}

Kultur sekolah dalam hubungan antarwarga sekolah ini sangat akan sangat diwarnai oleh gaya kepemimpinan kepala sekolah. Hubungan tersebut harus dilandasi dengan sikap saling menghargai, saling menghormati, saling ingat mengingatkan dalam kebenaran dan kesabaran (Q.S. Al 'Asyr), yang dibingkai dalam rasa persaudaraan. Persaudaraan secara umum mencakup saudara sekemanusiaan dan saudara semakhluk dan seketundukan kepada Allah. (Shihab, 2000: 486).

\section{Pembelajaran (Kegiatan Intrakurikuler)}

Pembelajaran di kelas, hendaknya dikemas sesuai prinsip-prinsip pendidikan humanistik, sehingga nuansa yang muncul dapat memberikan gerak bagi potensi siswa untuk berkembang. Rujukan proses yang diterapkan adalah: Subjek didik aktif, bukan pasif; guru bukan mengisi akal pikiran dengan banyak informasi, tetapi memandu keaktifan dan memberikan arahan. Guru sebagai rujukan otoriter dan pengarah ruang kelas harus diubah sebagai penasihat, pembimbing, dan pemandu belajar.
Guru sebagai teman senior siswa. Karena sekolah sebagai miniatur masyarakat besar, materi pelajaran perlu dikontekskan dengan kehidupan siswa. Dengan materi yang bermakna, siswa bisa mendapatkan proses pembelajaran dalam kehidupan. Oleh karena itu, materi kajian lebih diarahkan pada pemecahan masalah dan problem-problem kehidupan yang dialami siswa. Atmosfer sosial sekolah yang sering dirasa membelenggu siswa dengan aturan-aturan kaku harus diubah agar bersifat kooperatif dan demokratis sehingga siswa terhumanisasikan. Penekanan pada keunikan anak secara perorangan akan memungkinkan anak "mengaktualisasikan diri", sehingga membantu subjek didik secara perorangan dalam menemukan, menjadi, mengembangkan kedirian sejati dan keutuhan potensi.

Penciptaan lingkungan pembelajaran siswa yang terbebas dari persaingan intens, disiplin kaku, dan rasa takut akan kegagalan. Penciptaan lingkungan pembelajaran yang "akrab" antara pendidik dan subjek didik, sehingga tumbuh rasa aman dan tumbuh rasa kepercayaan bagi subjek didik terhadap pendidiknya. Siswa terbebas dari rasa takut yang merusak dan memakan energi, yang semestinya dapat dikeluarkan untuk pertumbuhan dan perkembangan perorangan dalam mengembangkan kreativitas. Penciptaan lingkungan pembelajaran yang tidak mengekang. Para pendidik atau guru bisa paling mudah menjangkau siswanya melalui kerja sama dengan orang-orang dan kelompok-kelompok kecil

\section{Pengembangan Diri (Kegiatan Ekstrakuri- kuler)}

Kegiatan ekstra kurikuler perlu dirancang dan dikemas sesuai bakat dan minat siswa. Pengelolaan kegiatan ekstra kurikuler sebagai berikut. Siswa berkembang sesuai dengan kodrat kemanusiaannya. Manusia berkehendak "bebas" sehingga dia memilih dan harus tahu apa yang dipilih itu. Anak bisa berkembang kreativitasnya karena bebas dari persaingan intens, tidak dikekang dengan disiplin kaku, dan juga tidak dihantui dengan rasa akan kegagalan. Anak tumbuh kepercayaan dirinya dan tumbuh 
kepercayaannya untuk bisa mempercayai orang lain; tumbuh rasa aman dalam dirinya dan bisa menciptakan keamanan bagi orang lain, dan dampaknya, bisa menghormati orang lain. Anak bisa mengaktualisasikan diri karena pendidikan humanis tidak menonjolkan penguasaan pengetahuan sebagai satu-satunya tujuan. Muncul rasa bisa bekerja sama dengan orang lain karena terbiasa dihargai harkat dan martabat kemanusiaannya.

\section{Bimbingan Ibadah}

Bimbingan ibadah di sini terutama pada ibadah-ibadah wajib, seperti shalat lima waktu dan puasa. Bimbingan ibadah yang dimaksud adalah dalam hal pengimplementasian lima dimensi secara utuh. Lima dimensi itu yakni aspek keimanan, aspek keilmuan, aspek penghayatan, aspek ritual atau praktik itu sendiri, aspek dampak atau implikasi dalam segala aspek kehidupan.

Selain ibadah wajib, bimbingan juga perlu ditujukan pada ibadah-ibadah sunnah, seperti shalat rowatib, shalat dhuha, shalat malam, dan lain-lain. Ibadah sunnah itu lebih menuntut keikhlasan yang tinggi. Oleh karena itu, bimbingan ikhlas ini harus dilakukan secara konsisten. "Ikhlas" adalah mengarahkan seluruh amal perbuatan semata kepada Allah, bukan yang lain

Ibadah shalat malam, dan shalat fajar terutama, menuntut keikhlasan yang tinggi. Ibadah ini sangat dianjurkan dalam Islam. Dengan menjalankan shalat fajar maupun shalat malam, akan mudah seseorang mencapai keikhlasan dan kekhusu'an. Dengan kondisi ikhlas dan khusu', seseorang hanya akan mengingat Allah SWT, bukan yang lain"'Orang-orang yang beriman dan hati mereka menjadi tenteram dengan mengingat Allah. Ingatlah, hanya dengan mengingat Allah-lah hati menjadi tenteram”. (Q.S. Ar Ra'ad:28).

\section{Pelayanan Bimbingan dan Konseling (BK)}

Adz Dzaky mengemukakan bahwa metode dalam membimbing dan mengarahkan peserta didik dalam perbaikan, perubahan, dan pengembangan yang lebih positif antara lain adalah sebagai berikut.

\section{Teori Al Hikmah}

Ciri konseling dengan Al Hikmah meliputi (1) mengharap adanya pertolongan Allah, (2) diagnosa dengan metode "intuisi", (3) ketauladanan dan kesalihan konselor, (4) terapi yang digunakan adalah nasihat-nasihat dengan teknik Illahiyah, yakni do'a dan kembali kepada Al Qur'an berkenaan dengan esensi permasalahan yang dialami.

\section{Teori Al Mau'idzah Al Khasanah}

Yakni teori bimbingan atau konseling dengan cara mengambil pelajaran-pelajaran atau itiba'-itiba' kehidupan pada Nabi dan Rasul-Rasul Allah, bagaimana Allah membimbing dan mengarahkan cara berfikir, cara berperasaan, berperilaku, dan memecahkan problem kehidupan; bagaimana cara membangun ketaatan, ketaqwaan, kepada-Nya, mengembangkan eksistensi diri, menemukan jati dan citra diri; dan bagaimana agar tidak terjerumus kepada hal-hal yang bisa merusak mental spiritual dan moral.

Teori Al Mau'idzah Al Khasanah bersumber dari: (1) Al Qur'an, (2) As Sunnah (perilaku Rasulullah, (3) Al Atsar (perilaku para sahabat nabi), (4) pendapat atau ijtihad para ulama Muslim, (5) pendapat para ahli psikoanalitik seperti Freud, eksistensial-humanistik Maslow dan lain-lain, client centered dari Carl Rogers dan lain-lain.

\section{Teori "Mujadalah" yang Baik}

Teori mujadalah merupakan teori konseling yang berpendapat bahwa seorang klien sedang dalam kebimbangan mencari kebenaran dari permasalahan dan kesulitan dalam mengambil keputusan tentang dua hal/lebih. Prinsipprinsip khas teori ini adalah perlu kesabaran tinggi dari konselor, penguasaan permasalahan oleh konselor serta solusinya, saling mengormati dan menghargai, bukan menjatuhkan dan menyalahkan, tetapi membimbing klien, penuh persaudaraan dan kasih sayang, dengan bahasa yang mudah difaham dan santun, tidak menyinggung perasaan klien, dengan dalil-dallil 
Al Qur'an secara tepat, dan ketauladanan sejati (Adz-Dzaky, 2004:205).

\section{PENUTUP}

Pertama, aktualisasi nilai humanis-religius para siswa pada pendidikan Madrasah Aliyah di Kulon Progo masih rendah. Hal tersebut ditunjukkan bahwa karakteristik nilai religiusitas siswa yang tidak utuh, yakni baru sebatas dimensi "ritual" dan dimensi "ilmu". Dimensi "iman", "eksperiensial", dan "konsekuensial" belum menyatu utuh dalam diri siswa.

Kedua, pengembangan pola pendidikan nilai humanis-religius siswa berbasis kultur madrasah ini, dilaksanakan dengan langkahlangkah sesuai konseptual model di atas. (1) Pemotretan kultur madrasah yang meliputi $m a$ terial culture dan behavioral culture, yang pada akhirnya ditemukan makna kultur positif dan negatif. (2) Penentuan Visi dan Misi Madrasah, dirancang dalam program dibidang artifak. (3) Pendidikan nilai humanis-religius diimplentasikan melalui saluran kultur madrasah yang meliputi: (1) sistem kepemimpinan kultural kepala madrasah, guru dan tata usaha; (2) model $h u$ man relation yang humanis-religius; (3) peran guru dan siswa dalam kegiatan intrakurikuler dan ekstrakurikuler; (4) pelayanan Bimbingan Konseling yang humanis-religius; (5) format kegiatan bimbingan ibadah yang komprehensif, serta audiensi dengan orang tua ataupun tokoh masyarakat.

Ketiga, hasil perubahan yang terjadi pada perilaku siswa setelah dilakukan tindakan pengembangan kultur madrasah adalah aktualisasi nilai religiusitas dan humanis meningkat, pola pendidikan dapat memberi kebebasan siswa dalam beraktualisasi diri, sikap peserta didik menjadi lebih "terbuka" dan "dekat" dengan pendidik, kreatif serta berprestasi dalam bidang yang ditekuni, dan temuan di lapangan menunjukkan bahwa, ada sejumlah siswa yang tidak bisa mengikuti norma-norma yang ada, baik norma agama, norma sosial, maupun norma ketertiban sekolah. Hal tersebut lebih disebabkan oleh karakter siswa yang terbentuk terutama dari faktor keluarga dan teman pergaulan.

\section{UCAPAN TERIMA KASIH}

Ucapan terima kasih kami sampaikan kepada berbagai pihak atas bantuannya dalam penelitian ini. Pertama, terima kasih kepada Direktur Dikti yang telah memberikan dana melalui Hibah Disertasi Doktor. Kedua, ucapan terima kasih dihaturkan kepada Prof. Dr. Sodiq A. Kuntoro, Prof. Dr. Sutrisno, M.Ag., yang telah membimbing selama penelitian berlangsung. Ketiga, ucapan terima kasih kepada teman sejawat FGD, para Kepala Madrasah beserta stafnya di MAN se Kabupaten Kulon Progo, para guru "Tim Pengembang Pendidikan Nilai" di MAN Wates 1, yang telah membantu pelaksanaan penelitian. Keempat, penulis juga mengucapkan terima kasih kepada Pengelola Jurnal Ilmiah Cakrawala Pendidikan, Universitas Negeri Yogyakarta yang telah menerbitkan hasil penelitian ini.

\section{DAFTAR PUSTAKA}

Adz-Dzaky, M. Hamdani Bakran. 2004. Konseling dan Psikologi Islam: Penerapan Metode Sufistik. Yogyakarta: Fajar Pustaka Baru

Al-Attas, M.Naquib. 1981. Islam dan Sekulerisme. Bandung: Pustaka.

Borg, Walter R. \& Gall, Meredith Damien. 1983. Educational Research An Introduction. New York: Longman Inc.

Deal, Terrence E. 1994. The Leadership Paradox: Balancing Logic and Artistry in School. San Francisco: Jossey-Bass Publishers.

Departemen Agama Republik Indonesia. 1989. Al-qur'an dan terjemah.Semarang: CV Toha Putra.

Ditjen Dikdasmen Depdiknas. 2002. Memahami Budaya Sekolah. Jakarta: Depdiknas.

Knight, George R. 1982. Issues and Alternatives in Educational Philosophy. Michigan: Andrews University Press. 
Manshur. 2012. "Penerapan Sistem Nilai dalam Budaya Organisasi Sekolah Unggul: Studi Multikasus", dalam Cakrawala Pendidikan XXXI (3), hlm.512-523.

Mulyana, Rohmad. 2004. Mengartikulasikan Pendidikan Nilai. Bandung: Alfabeta.

Nashori, H.F., \& Mucharam, R.D. 2002. Mengembangkan kreativitas dalam Perpektif Psikologi Islami. Yogyakarta: Menara Kudus Jogja.

Prasetyo, Eddy. 2007. "Tiga Hal Pokok Untuk Kembangkan Akhlak Mulia Anak", http: //www.era muslim.com./berita/nas. (Diunduh 19 Juli 2008).

Shihab, M.Quraish. 2000. Wawasan al-Quran. Bandung: Mizan.

Spradley, James P. 1979. The Etnographic Interview. New York: Harcourt Brace Jovanovich College Publishers.
Stark, Rodney. Glock, Charles Y. 1965. Religion and Society in Tension. Chicago: Rand Mc Nally \& Company

Sugiyana. 2006. Metode Penelitian Pendidikan: Pendekatan Kuantitatif, Kualitatif dan $R$ \& J. Bandung: Alfabeta.

Tim Peneliti PPs UNY. 2003. "Pedoman Pengembangan Kultur Sekolah." Laporan Penelitian Kerjasama Direktorat Dikmenum Depdiknas-PPs UNY.

Usman, Husaini \& Raharjo, Eko Nuryadin. 2013. "Strategi Kepemimpinan Pembelajaran Menyongsong Implementasi $\mathrm{Ku}-$ rikulum 2013", dalam Cakrawala Pendidikan, XXXII (1), hlm.1-13. 